\title{
STUDENT PERSPECTIVES OF CHEATING IN ONLINE CLASSES
}

\author{
David M. Douglas, Robert Morris University,douglas@rmu.edu \\ Karen Paullet, Robert Morris University, paullet@rmu.edu \\ Adnan Chawdhry, California University of PA, chawdhry_A@calu.edu
}

\begin{abstract}
Distance education continues to grow in popularity, partially due to the convenience to students. Within the parameter of convenience, students are faced with ethical considerations when taking online classes. Ethics is the determining factor in what boundaries society has determined as appropriate behavior for our actions. In academia, ethics is a commonly tossed about phrase frequently intoned by institutional administrators and faculty. This exploratory study of 457 undergraduate students will assess the student's ethical perspectives about their own behavior and what external resources they deem as acceptable use in online courses. Additionally, it is important to understand how students' perspectives correlate with demographic characteristics and level of education in order for faculty and administrators to effectively develop online courses for their students.
\end{abstract}

Keywords: Online Learning, Student, Perspectives, Ethics, Distance Learning and e-Learning

\section{INTRODUCTION}

Ethics is the determining factor in what boundaries society has determined as appropriate behavior for our actions. There are, of course, ethical standards for all professions and for all measures of our existence. Some may say parts of our ethics are innate while others may say they are learned. It is the belief of the authors, that ethics is a learned behavior. To some, the beginning of our knowledge of ethics began with the bedtime stories read to us as children. To others it was lessons taught of right and wrong as we moved from infancy to maturity.

Ethics in academia is a commonly tossed about phrase frequently intoned by institutional administrators and faculty. The purpose of the commotion is to instill a sense of purpose and integrity into the learning experience for student and instructor alike.

Communication technology, as we are aware, can be either miraculous or mischievous. The miracles of course are local and global instantaneous communication anywhere and at any time. The mischievous can range from invasion of our digital privacy to its duplicitous use in plagiarism and testing conventions both inside and outside of the classroom environment.

Cheating is invariably tied to ethics. And ethics is likewise to morality. In academics and in life, our ethics and morality guide our lives. With the proliferation of perpetual connectivity through both static and mobile devices the opportunity to remain attached to the information grid and to those with whom we chose to associate. The new world order of the digital landscape has caused a paradigm shift in how both the student and the instructor view the protocols of test taking and the long standing tradition of old world academic integrity and thinking. This study will assess ethical implications of cheating in distance learning classes. The following research questions were explored:

RQ1: Is there a correlation between student's views of ethical conduct in online courses with age, gender, and level of education?

RQ2: Do university students deem it unethical to utilize external sources when taking online courses?

\section{LITERATURE REVIEW}

When considering ethics and distance education courses, the "age-old concerns about ethical practices in assessment - take on new twists in the distance-learning environment" $[12,1]$. The distance which separates students in online classes does not discourage academic dishonesty. In traditional brick and mortar classes, students pass notes or write answers in the palm of their hands if they want to cheat on an exam. Students in online classes do not have to be so 
clever since in most instances, they are not being monitored during an exam. Using the Internet to search for answers, having another person take the exam or sharing the answers with other classmates are forms of cheating for the online learner. It is becoming very hard for instructors of online classes to catch academic dishonesty.

The need for ethics in distance education is critical to student's success. When students interact face-to-face in traditional classes, they are able to understand inappropriate or unethical behavior [5, 14]. When technology comes into play as with distance learning classes, conducting ethical behavior feels less personal because they are unable to see the instructor on the other side of the screen. To address ethics in online courses, Gearhart [5] suggests setting policies that provide a framework for students to follow and incorporate ethics into the curriculum.

A 2008 study conducted by Toprak, Ozkanal, Kaya and Aydin, analyzed ethics in e-learning. The authors believe that instructors and the institution need to determine their own ethical responsibilities. The expectations must be made at the beginning of the course. Institutions should also have e-Learning policies, guides on legal issues and preventative measures for privacy, plagiarism and copyrights in place [9]. Often time's problems arise when students are not aware of their ethical responsibilities. Students must accept responsibility for the courses they take and participate authentically and refrain from cheating [14].

Ethics has many attachments to its label. There is ethical egoism, ethical pluralism, ethical relativism, and ethical will. Each has their own unique modifiers and attributes depending on its usage. Additionally, the ethicist must also include ethics of conduct and ethics of virtue when considering the scholarship of ethics [15]. In it is imperative to define what is right and wrong in online classes so that students understand the expectations and norms of the class.

Academic dishonesty is an area of concern for both brick-and-mortar and online academic instructions. In traditional classrooms, faculty can usually monitor student's activities where they are able to put a face to an actual student. As of May 2014, there are approximately, 5.5 million students who took at least one online course [11]. Courses offered online pose a challenge to educators as students work independently and with very little monitoring by the instructor. Online courses appear to remove barriers of instructor observation and can provide students with an increased opportunity to cheat [5]. According to Grijalva [6] it is often believed that since students and faculty do not interact face-to-face in most online classes that students will engage in a higher number of cheating incidents than students attending traditional classes.

A 2013 Josephson Institute white paper discussed particular aspects of the, "Domains of Student Development: academic, social/emotional, and character." One particular aspect of debate was: "Thus, whether included in formal standards or not, educational institutions are expected to provide students with knowledge, skills, values, and character traits in three distinct domains of development. The three traits are detailed below. "1) Academic instilling educational values, beliefs, and attitudes; developing learning-related character traits and cognitive skills. 2) Social/Emotional - instilling self-awareness and self-management skills, interpersonal skills, and positive life skills and character traits. 3) Character - instilling or strengthening core ethical values and moral character traits" [8].

A study published by Jones [7] listed numerous scenarios on what students consider to be cheating or plagiarizing. The following list provide a few examples: submitting another's work as your own, purchasing a research paper or downloading the document from the Internet, cutting and pasting online material without citations, "lifting more than 10 consecutive words from a document without proper acknowledgement," direct copying of an original source document without citation, and submitting assignments used in previous classes

[7].

According to Bunn, Caudill and Gropper, [2], it is believed that students cheating behavior can be broken down into two categories. The first is planned cheating which can involve using notes, copying homework, and plagiarizing. Students should be aware that what they are doing is wrong. The second is panic cheating, which can happen when a student is in the middle of taking an exam. While taking the exam they realize that they are not prepared and look over at another students work for answers. In online courses, planned cheating might be more common than panic cheating due to the nature of the online environment [6] When taking an exam online, students can search for answers online or through the course textbook, by asking a friend for help or they might have another person take the exam. 
Kelly \& Bonner [10] examined a population of faculty and administrator perceptions concerning academic dishonesty in distance education environments. "Respondents ranked their top three choices for the reasons students cheat as: 1) grade pressure, 2) uncertainty about what constitutes academic dishonesty, and 3) laziness" [10]. Educators past and present should be able to identify with the aspects of grade pressure and laziness as unambiguous culprits. However the uncertainty aspect of what constitutes academic dishonesty is perplexing. One would hope that by the time a student reaches a post-secondary educational experience they would have learned institutional guidelines of academic integrity and ethics.

Perez-Pena [13] debated the pervasiveness of student cheating at prestigious academic have worsened over the past several decades. The author discussed how a study by Jeffrey A. Roberts and David M. Wasieleski from Duquesne University discerned that as the prevalence of online tools increases so does the likelihood of students copying the work of others. Instant access to the Internet and the ability to download information "...has loosened some ideas of ownership and authorship." To quote Wasieleski, "Students are surprisingly unclear about what constitutes plagiarism or cheating."

\section{METHODOLOGY}

With the advent of newer technologies to support distance education in the academic environment, universities need to evaluate academic integrity by understanding students' ethical views of conduct while taking online courses. However, the convenience that distance education provides educators, administrators, and students sometimes overshadows the need to evaluate ethical student conduct within online courses, which could potentially introduce the risk of having students use external sources to complete classwork. The study explores the following two research questions:

RQ1: Is there a correlation between student's views of ethical conduct in online courses with age, gender, and level of education?

RQ2: Do university students deem it unethical to utilize external sources when taking online courses?

The study examined students at two small mid-Atlantic Universities during the month of April 2014. The research utilized a quantitative methodology to assess students' ethical views and how they correlate to demographic attribute. The population chosen for this study was comprised of undergraduate and graduate students enrolled in on-campus and online programs of study. Undergraduate students and graduate students were surveyed in order to gather data from students 18 years of age and older. A total of 457 respondents completed the survey. The survey was designed to obtain information on the respondents' experience with online distance education classes, how they completed their coursework, and if they ever allowed others to complete work on their behalf. Additionally, the survey addressed methods, if any, used to validate student identities in their online courses. The survey was conducted using Survey Monkey, an online tool, to gather and organize data. The data was imported into SPSS for further analysis. This study used Chi-square with a statistical significance at the .05 margin of error with a $95 \%$ confidence level. The study was a convenience sample surveying students from all departments within the university which included the School of Arts and Humanities, Business, Science and Math, Engineering, Computer Science, Information Technology, Criminal Justice and Psychology.

The survey instrument consisted of 18 closed-ended questions and two open ended questions for further understanding of participant comments and responses. The first three questions focused on student demographics; which included gender, age, and education level. Questions 4 through 18 asked students if they completed an online course, methods used for student validation, tools / external sources used to complete assignments and exams, their ethical opinion of utilizing external sources measured through 5 choices (Strongly Agree, Somewhat Agree, Neutral, Somewhat Disagree, Strongly Disagree), and their self-assessment of their own personal philosophy when completing online course work. The final two questions asked the students of methods they felt could be implemented in an effort to validate student identities and any additional comments they may have about the topic. 


\section{RESULTS}

The survey responses were analyzed at both universities and recorded as either University A or University B. University A had students ranging from 18 years of age to 63 years and University B had students ranging from 18 to 47 years of age. Similarly, the study determined that University A had approximately $33.5 \%$ Male students and $66.5 \%$ female students. University B had a similar distribution with $41.4 \%$ Males and $58.6 \%$ females.

The next set of questions determined if students had taken online classes and if so, were authentication methods such as Skype or Biometrics used to validate a student's identity. It is important to note that if students responded "No" to taking an online class, the survey immediately concluded. Both universities had a strong response rate of students who took at least one online class. University A had a $94.2 \%$ response rate of students who took at least one online class while University B had an $87.5 \%$ response rate of students who took at least one online class.

To better understand students' ethical perspectives, each participant was asked if they felt it was ethical to use external resources when taking an online class. Approximately $20 \%$ at each university felt that using external resources when taking an online course was unethical. It is important to note that the survey indicated a list of external resources including mobile devices, other individuals, internet searches, and copies of the exams. A majority of students felt that using external resources was ethically acceptable when taking an online class. A breakdown of these results for both University A and University B can be seen in Table 1.

Table 1. External Resources for Online Class

\begin{tabular}{lcc}
\hline & University A & University B \\
\hline Strongly Agree & $7.55 \%$ & $12.96 \%$ \\
Somewhat Agree & $11.64 \%$ & $9.26 \%$ \\
Neutral & $17.92 \%$ & $31.48 \%$ \\
Somewhat Disagree & $23.27 \%$ & $14.82 \%$ \\
Strongly Disagree & $39.62 \%$ & $31.48 \%$ \\
Total & $100.00 \%$ & $100.00 \%$ \\
\hline
\end{tabular}

Additionally, students were asked about their ethical view of using external resources when taking online exams. Opposing their view of using external resources when taking online courses, approximately $61 \%$ of the students at each university felt using external resources when taking an online exam was unethical. Both universities had less than $25 \%$ of the respondents who felt that using external resources while taking an online exam was ethical. Further details of the respondents for each university can be seen in Table 2.

Table 2. External Resources for Online Exams

\begin{tabular}{lcc}
\hline & University A & University B \\
\hline $\begin{array}{l}\text { Strongly } \\
\text { Agree }\end{array}$ & $26.65 \%$ & $27.77 \%$ \\
$\begin{array}{l}\text { Somewhat } \\
\text { Agree }\end{array}$ & $27.90 \%$ & $25.93 \%$ \\
Neutral & $26.96 \%$ & $22.22 \%$ \\
$\begin{array}{l}\text { Somewhat } \\
\text { Disagree }\end{array}$ & $12.23 \%$ & $16.67 \%$ \\
$\begin{array}{l}\text { Strongly } \\
\text { Disagree }\end{array}$ & $6.26 \%$ & $7.41 \%$ \\
Total & $100.00 \%$ & $100.00 \%$ \\
\hline
\end{tabular}

Students were asked to gauge their level of ethics when comparing themselves to other students. At both universities, greater than $60 \%$ of the students felt they were either very ethical or average ethical in comparison to 
other students. University A reported a very small percentage of students who stated they were unethical in comparison to other students. Lastly, University A and University B students reported $29.69 \%$ and $34.0 \%$, respectively, that they felt somewhat ethical in comparison to other students. A detailed breakdown of these results is available in Table 3 .

Table 3. Self-Evaluation Ethical Comparison

\begin{tabular}{lcc}
\hline & University A & University B \\
\hline Very ethical & $43.74 \%$ & $34.0 \%$ \\
Average ethical & $25.63 \%$ & $32.0 \%$ \\
Somewhat ethical & $29.69 \%$ & $34.0 \%$ \\
Unethical & $0.94 \%$ & $0 \%$ \\
Total & $100.00 \%$ & $100.00 \%$ \\
\hline
\end{tabular}

One of the objectives of the study was to understand if any statistical correlation existed between demographic characteristics and level of education with the students' responses to the self-evaluation question detailed in Table 3. It was determined that both Age and Level of Education were statistically significant with chi-square values of 0.00 and 0.01 , respectively. The results were determined to be statistically significant if their chi-square value was less than .05 , assuming a 95\% margin of error. A similar analysis was done for University B, however, only the students' responses illustrated that only Level of Education was statistically significant in comparison to their selfevaluation responses. Additional metrics for these two universities can be found in Tables 4 through 11 .

Table 4. Statistical Correlation University A

\begin{tabular}{lccc}
\hline & Chi Square Value & df & Value \\
\hline Age & 0.00 & 36.00 & 72.88 \\
Gender & 0.56 & 8.00 & 6.80 \\
Level of Education & 0.01 & 20.00 & 38.78 \\
\hline
\end{tabular}

Table 5. Statistical Correlation University B

\begin{tabular}{lccc}
\hline & Chi Square Value & df & Value \\
\hline Age & 0.13 & 15.00 & 21.13 \\
Gender & 0.45 & 6.00 & 5.74 \\
Level of Education & 0.00 & 9.00 & 29.11 \\
\hline
\end{tabular}

Table 6. Age versus Self-Evaluation University A

\begin{tabular}{ccccc}
\hline Age & Unethical & $\begin{array}{c}\text { Somewhat } \\
\text { Ethical }\end{array}$ & $\begin{array}{c}\text { Average } \\
\text { Ethical }\end{array}$ & $\begin{array}{c}\text { Very } \\
\text { Ethical }\end{array}$ \\
\hline $\mathbf{1 8 - 2 2}$ & $0.51 \%$ & $18.58 \%$ & $9.92 \%$ & $6.36 \%$ \\
$\mathbf{2 3 - 2 7}$ & $0.00 \%$ & $12.72 \%$ & $7.12 \%$ & $10.18 \%$ \\
$\mathbf{2 8 - 3 2}$ & $0.25 \%$ & $3.56 \%$ & $1.53 \%$ & $4.83 \%$ \\
$\mathbf{3 3 - 3 7}$ & $0.00 \%$ & $1.53 \%$ & $1.02 \%$ & $3.05 \%$ \\
$\mathbf{3 8 - 4 2}$ & $0.00 \%$ & $1.78 \%$ & $0.25 \%$ & $3.31 \%$ \\
$\mathbf{4 3 - 4 7}$ & $0.00 \%$ & $2.04 \%$ & $0.00 \%$ & $3.82 \%$ \\
$\mathbf{4 8 - 5 2}$ & $0.00 \%$ & $1.02 \%$ & $0.51 \%$ & $1.27 \%$ \\
$\mathbf{5 3 - 5 7}$ & $0.00 \%$ & $0.51 \%$ & $0.00 \%$ & $2.04 \%$ \\
$\mathbf{5 8 - 6 2}$ & $0.00 \%$ & $0.51 \%$ & $0.25 \%$ & $0.76 \%$ \\
\hline
\end{tabular}




\begin{tabular}{lcccc}
\hline $\mathbf{6 3}+$ & $0.00 \%$ & $0.51 \%$ & $0.25 \%$ & $0.00 \%$ \\
Total & $0.76 \%$ & $42.75 \%$ & $20.87 \%$ & $35.62 \%$ \\
\hline
\end{tabular}

Table 7. Gender versus Self-Evaluation University A

\begin{tabular}{lllll}
\hline Gender & Unethical & Somewhat Ethical & Average Ethical & Very Ethical \\
\hline Female & $0.26 \%$ & $26.60 \%$ & $14.32 \%$ & $25.32 \%$ \\
Male & $0.51 \%$ & $16.11 \%$ & $6.65 \%$ & $10.23 \%$ \\
Total & $0.26 \%$ & $26.60 \%$ & $14.32 \%$ & $25.32 \%$ \\
\hline
\end{tabular}

Table 8. Level of Education versus Self-Evaluation University A

\begin{tabular}{llllc}
\hline Level of Education & Unethical & Somewhat Ethical & $\begin{array}{c}\text { Average } \\
\text { Ethical }\end{array}$ & $\begin{array}{c}\text { Very } \\
\text { Ethical }\end{array}$ \\
\hline Graduate Masters & $0.26 \%$ & $16.11 \%$ & $8.70 \%$ & $19.69 \%$ \\
$\begin{array}{l}\text { Undergraduate } \\
\text { Senior }\end{array}$ & $0.26 \%$ & $14.07 \%$ & $6.14 \%$ & $9.46 \%$ \\
$\begin{array}{l}\text { Undergraduate } \\
\text { Junior }\end{array}$ & $0.00 \%$ & $5.12 \%$ & $3.58 \%$ & $3.84 \%$ \\
$\begin{array}{l}\text { Undergraduate } \\
\begin{array}{l}\text { Sophomore } \\
\text { Undergraduate }\end{array}\end{array}$ & $0.26 \%$ & $3.84 \%$ & $1.53 \%$ & $2.05 \%$ \\
Freshman & $0.00 \%$ & $3.84 \%$ & $1.02 \%$ & $0.26 \%$ \\
\hline
\end{tabular}

Table 9. Age versus Self-Evaluation University B

\begin{tabular}{lcccc}
\hline Age & Unethical & Somewhat Ethical & $\begin{array}{c}\text { Average } \\
\text { Ethical }\end{array}$ & Very Ethical \\
\hline $\mathbf{1 8 - 2 2}$ & $0.00 \%$ & $31.25 \%$ & $20.31 \%$ & $9.38 \%$ \\
$\mathbf{2 3 - 2 7}$ & $0.00 \%$ & $1.56 \%$ & $4.69 \%$ & $1.56 \%$ \\
$\mathbf{2 8 - 3 2}$ & $0.00 \%$ & $6.25 \%$ & $0.00 \%$ & $4.69 \%$ \\
$\mathbf{3 3 - 3 7}$ & $0.00 \%$ & $1.56 \%$ & $1.56 \%$ & $7.81 \%$ \\
$\mathbf{3 8 - 4 2}$ & $0.00 \%$ & $3.13 \%$ & $0.00 \%$ & $3.13 \%$ \\
$\mathbf{4 3 - 4 7}$ & $0.00 \%$ & $1.56 \%$ & $0.00 \%$ & $1.56 \%$ \\
Total & $0.00 \%$ & $45.31 \%$ & $26.56 \%$ & $28.13 \%$ \\
\hline
\end{tabular}

Table 10. Gender versus Self-Evaluation University B

\begin{tabular}{lllll}
\hline Gender & Unethical & $\begin{array}{c}\text { Somewhat } \\
\text { Ethical }\end{array}$ & $\begin{array}{c}\text { Average } \\
\text { Ethical }\end{array}$ & Very Ethical \\
\hline Female & $0.00 \%$ & $17.46 \%$ & $12.70 \%$ & $12.70 \%$ \\
Male & $0.00 \%$ & $26.98 \%$ & $14.29 \%$ & $15.87 \%$ \\
Total & $0.00 \%$ & $44.44 \%$ & $26.98 \%$ & $28.57 \%$ \\
\hline
\end{tabular}


Table 11. Level of Education versus Self-Evaluation University B

\begin{tabular}{lllll}
\hline $\begin{array}{l}\text { Level of } \\
\text { Education }\end{array}$ & Unethical & $\begin{array}{c}\text { Somewhat } \\
\text { Ethical }\end{array}$ & $\begin{array}{c}\text { Average } \\
\text { Ethical }\end{array}$ & Very Ethical \\
\hline $\begin{array}{l}\text { Graduate } \\
\text { Masters }\end{array}$ & $0.00 \%$ & $3.13 \%$ & $0.00 \%$ & $0.00 \%$ \\
$\begin{array}{l}\text { Undergraduat } \\
\text { e Senior }\end{array}$ & $0.00 \%$ & $12.50 \%$ & $10.94 \%$ & $6.25 \%$ \\
$\begin{array}{l}\text { Undergraduat } \\
\text { e Junior }\end{array}$ & $0.00 \%$ & $17.19 \%$ & $4.69 \%$ & $10.94 \%$ \\
$\begin{array}{l}\text { Undergraduat } \\
\text { e Sophomore }\end{array}$ & $0.00 \%$ & $45.31 \%$ & $26.56 \%$ & $28.13 \%$ \\
$\begin{array}{l}\text { Undergraduat } \\
\text { e Freshman }\end{array}$ & $0.00 \%$ & $12.50 \%$ & $10.94 \%$ & $10.94 \%$ \\
\hline
\end{tabular}

\section{DISCUSSION}

The first research question looked at both universities to see if a correlation existed between the respondents' selfevaluation question and the three variables (age, gender, and level of education). The greatest response rate was centered on "Somewhat ethical in comparison to other students", while it was important to see that a very limited number of students at University A and no students at University B felt that they were "Unethical" in comparison. Given the low response rate for "Unethical", one could assume that students did not want to be categorized in such a taboo grouping and may have decided to choose the next ranking of "Somewhat" which led to the larger response rate. Additionally, males seemed to evaluate themselves as less ethical in comparison to the females.

University A found both age and Level of Education to be statistically significant with the self-evaluation, while University B found that only Level of Education was statistically significant. Based upon the results, it seems as age increased, students felt they were more ethical in comparison to other students. Additionally, level of education yielded similar results with higher levels of education illustrating those students felt they had a higher level of ethics. When looking at these two results, age can be correlated with level of education being that as we move into the next year of our academic career, we are getting older and have gained additional life / academic experiences that may mold our ethical principles. In a nutshell, as we get older, students find themselves being more ethical. Therefore faculty and administrators may consider using less ethical and academic integrity measures for advanced courses or courses with students higher in age.

The second research question focused on the students' perspectives of using external resources such as mobile devices and internet searches in their courses and online courses and exams. The results illustrated that the majority of students recognized that exams are meant to test what they have learned and using external resources would unethical when taking an online exam. However, students felt using external resources when completing coursework outside of exams was acceptable and ethical.

It can be assumed that students are leveraging external resources to help enhance their knowledge on the covered topics. Given these two statistics, it would be recommended that faculty and administrators continue to improve online exams to help combat external resources being used or implement exams that would allow external resources but go past the simple definitional / theory questions to test the students' abilities of applying the learned concepts. Lastly, it would also be recommended that courses incorporate external resources in their overall course rather than finding methods to exclude them. Many learn best by researching the topic outside of the course shell. Given that students find the use acceptable, we should embrace it and allow them to broaden their knowledge rather than restricting them to content solely in the course shell. 


\section{CONCLUSIONS}

Academic integrity has long plagued the educator. From grade school neophytes to doctoral degree candidates the temptation to and the admission of cheating endures. Cheating is perhaps not the most politically correct or sensitive description of academic dishonesty. But that is exactly what it is. Cheating is cheating. It does not matter if one is plagiarizing another's work, using crib sheets, or using an ancillary electronic device to circumvent security protocols when completing exams or other assignments.

Mobile device ubiquity and its simplicity of use have brought the world to the students' fingertips. Information, be it right or wrong, is only a click or two away. It is no small wonder that students are tempted to claim another's work or ideas as their own.

These facts can lead faculty and administrators down one of two paths. They must either find better ways to restrict the use of external resources or embrace its use and find creative ways to enhance the course. Like the old saying "if you can't beat them, join them," this is a prime opportunity for universities to enrich their online courses past simple postings of PowerPoints and exams and implement interactive course material that drives and motivates students to go beyond the course content and truly gain an in-depth knowledge of the course materials.

\section{REFERENCES}

1. Abott, L., Siskovic, H., Nogues, V, and Williams, J.G. (2000). Student assessment in multimedia instruction: Considerations for instructional designer. Retrieved from Eric on-line database (ED 444516 ) at http://newfirstsearch.oclc.org

2. Bunn, D.N., Caudill, S.B., and Gropper, D.M. (1992). Crime in the classroom: An economic analysis of undergraduate student cheating behavior. Journal of Economic Education, 23 (Summer): 197-207.

3. Davis, M.R. (2014, March 10). Adaptive tech, secure browsers aim to curb student cheating. Education Week, 33(25). Retrieved May 10, 2015 from http://www.edweek.org/ew/articles/2014/03/13/25cheating.h33.html?qs=cheating

4. Frost, J., Hamlin, A., \& Bar4cyzy, C. (2007). A survey of professor reactions to scenarios of academic dishonesty in American universities. Journal of Business Inquiry: Research, Education, and Application, 6 (1), $11-18$

5. Gearhart, D., (2001). Ethics in distance education: Developing ethical policies. Online Journal of Distance Learning Administration, Vol. IV, No 1

6. Grijalya, T., Kerkyliet, J., \& Nowell, C. (2002). Academic Honesty and Onli9ne Courses. Retrieved April 20, 2015 from http://oregonstate.edu/dept/econ/pdf/cheat.online.pap6.pdf

7. Jones, D.L.R. (2011 June). Academic dishonesty: Are more students cheating? Business Communication Quarterly, 74 (2), 141-150.

8. Josephson Institute. (2013). Model standards for academic, social, emotional, and character development: Critical educational outcomes. Retrieved May 2, 2014 from http://charactercounts.org/pdf/Model-Standards.pdf

9. Khan, BAdrul, (2005). Managing e-learning strategies: design, delivery, implementation and evaluation. Information Science Publishing, Hershey, PA, pp. 310-324

10. Kelly, L.B., \& Bonner, L. (2005). Digital test, distance education and academic dishonest: Faculty and administrator perceptions and responses. Journal of Asynchronous Learning Networks. 9(1), 43-52. Retrieved from http://www.msmc.la.edu/include/learning_resources/online_course_environment/online_teaching/v9n1_dishone sty.pdf

11. Kolowich, S. (2014, January). Exactly how many students take online courses? The Chronical of Higher Education. Retrieved May 2, 2015 from http://chronical.com/blogs/wiredcampus/exactly-how-many-studentstake-online-course $/ 49455$

12. Olt, M. (2002). Ethics and distance education: Strategies for minimizing academic dishonesty in online assessment. Retrieved from http://www.westga.edu-distance/ojdla/fall53/olt53.pdf

13. Perez-Pena, R. (2012, September 7). Studies find more students cheating with high achievers no exceptions. The New York Times. Retrieved May 25, 2015 from http://www.nytimes.com/2012/09/08/education/studiesshow-more-students-cheat-even-high-achievers.html?_r=1\&\&pagewanted=print 
14. Roprak, E., Ozkanal, B., Kaya, S., \& Aydin, S. (2006). What do learners and instructors of online learning environments think about ethics in e-learning: A case study form anadolu university. Retrieved from $\mathrm{http}$ ://asianvu.com/digital-library/elearning/ethics.pdf

15. Rosenstand, N. (2013). The moral of the story: An introduction to ethics. ( $7^{\text {th }}$ ed.) New York: McGraw Hill. 